\title{
A novel method of achieving haemostasis in transfusion-dependent small bowel malignancy-related bleeding
}

\author{
Nowlan Selvapatt, Jonathan Hoare
}

Department of

Gastroenterology, St Mary's Hospital London, London, UK

\section{Correspondence to}

Dr Nowlan Selvapatt,

nowlan.selvapatt@imperial. ac.uk

Accepted 28 November 2014

\section{DESCRIPTION}

Significant bleeding from small bowel malignant lesions is a rare but challenging condition to manage endoscopically. Hemospray (TC-325; Cook Medical, Winston-Salem, USA) has increasingly been reported to be effective in upper gastrointestinal lesions including malignancy. ${ }^{12}$ However, to date, no cases of its use in the small bowel have been reported. We describe its use in a transfusiondependent small bowel malignant lesion (video 1).

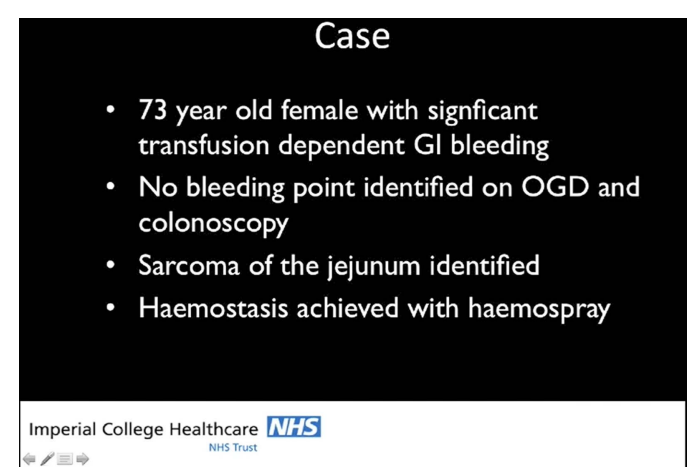

Video 1 Application of Hemospray in the jejunum to achieve haemostasis.
A 73-year-old woman, who had 6 months previously had a wedge resection of a gastric sarcoma, was referred with recurrent malaena with no cause found after six oesophagogastroduodenoscopys and colonoscopy. She required 34 units of blood over a 5 -week period. She was referred to our centre by her oncologists prior to her third cycle of chemotherapy, after a positron emission tomography CT had suggested evidence of small bowel activity.

On enteroscopy, successful intubation to approximately $11.5 \mathrm{~m}$ post pylorus revealed an irregular $2 \mathrm{~cm}$ ulcerated lesion that was spontaneously oozing large amounts of fresh blood (figure 1A, B). In order to achieve diagnostic certainty, a biopsy was carefully taken from the edge before the entire area was treated with generous application of Hemospray, which achieved haemostasis (figure 1C). Two tattoos were placed proximal to the lesion (figure 1D). The biopsy revealed gastric epitheliod angiosarcoma. Postprocedure the patient remained haemodynamically stable with no clinical evidence of further gastrointestinal bleeding. The patient underwent successful jejunal resection 7 days later with 1 further unit of blood transfusion electively preoperatively.

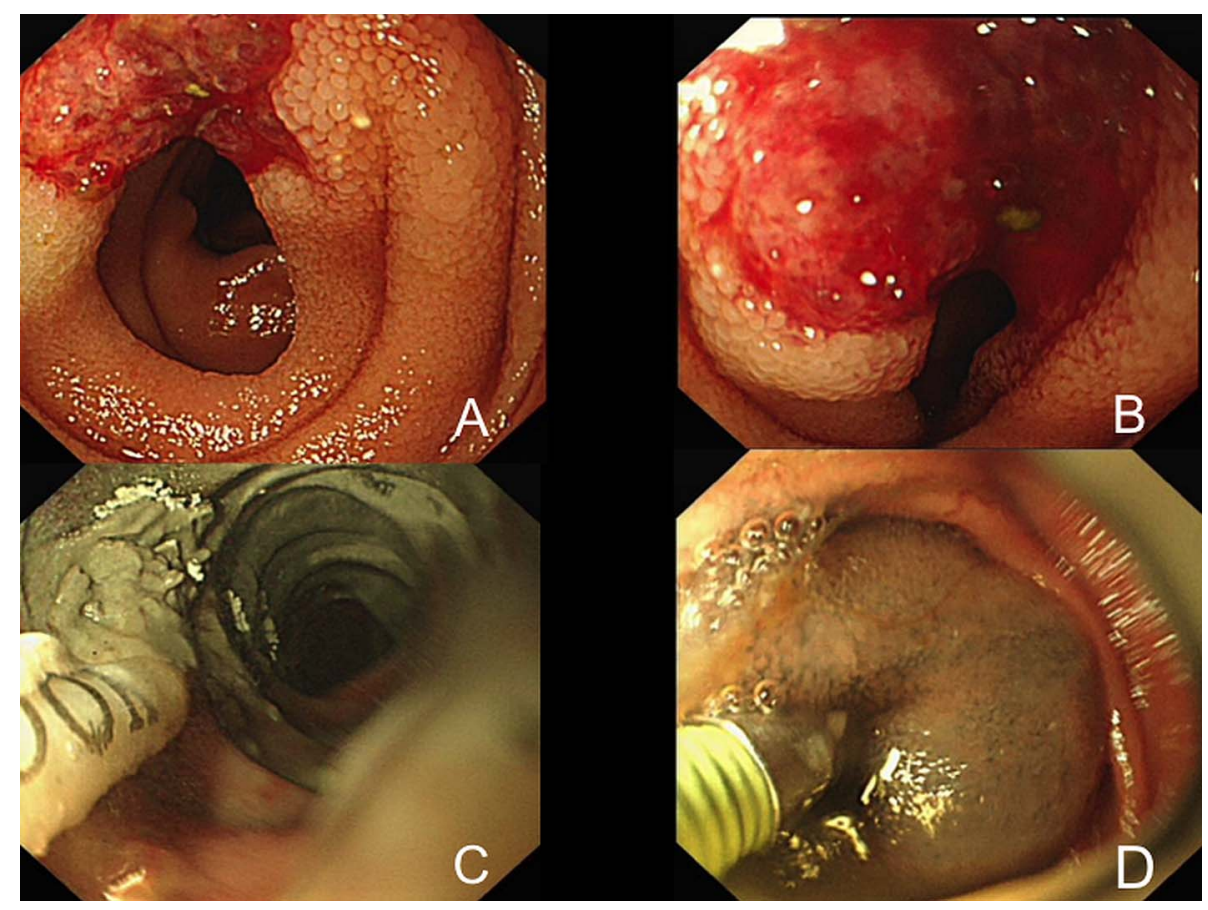

Figure 1 (A) Jejunal bleeding lesion, (B) close-up image of the jejunal sarcoma, (C) post deployment of Hemospray to achieve haemostasis and (D) proximal tattoo placement. 


\section{Learning points}

In the event of recurrent transfusion dependent gastrointestinal (GI) bleeding with no focus for treatment on oesophagogastroduodenoscopys and colonoscopy, small bowel pathology should be considered early.

- Hemospray is a feasible option for management of small bowel bleeding.

- Hemospray can be considered as a therapeutic option to achieve bridging haemostasis in malignant GI bleeding lesions, prior to definitive therapy.

Acknowledgements The authors would like to acknowledge the patient involved in this report for her kind support of the publication of this manuscript.
Contributors NS was responsible for taking the video and full manuscript write up. JH provided the intellectual input of novel use of Hemospray in this case and has fully been involved in the manuscript editorial.

Competing interests None.

Patient consent Obtained.

Provenance and peer review Not commissioned; externally peer reviewed.

\section{REFERENCES}

1 Sulz MC, Frei R, Meyenberger $C$, et al. Routine use of Hemospray for gastrointestinal bleeding: prospective two-center experience in Switzerland. Endoscopy 2014;46: 619-24.

2 Chen YI, Barkun AN, Soulellis C, et al. Use of the endoscopically applied hemostatic powder TC-325 in cancer related upper GI haemorrhage: preliminary experience (with video). Gastrointest Endosc 2012;76:1278-81.

Copyright 2014 BMJ Publishing Group. All rights reserved. For permission to reuse any of this content visit http://group.bmj.com/group/rights-licensing/permissions.

BMJ Case Report Fellows may re-use this article for personal use and teaching without any further permission.

Become a Fellow of BMJ Case Reports today and you can:

- Submit as many cases as you like

- Enjoy fast sympathetic peer review and rapid publication of accepted articles

- Access all the published articles

- Re-use any of the published material for personal use and teaching without further permission

For information on Institutional Fellowships contact consortiasales@bmjgroup.com

Visit casereports.bmj.com for more articles like this and to become a Fellow 